Cilt/Volume:13 Sayı/Issue:3 Aralık/December 2021 Özel Sayı / Special Issue

\title{
Pandemi Döneminde Çalışma Ortamlarında Oluşan Risk Faktörlerinin Değerlendirilmesi
}

\section{Evaluation Of Risk Factors In Working Environments During The Pandemic Period}

\author{
İlayda Ardıç ${ }^{1}$ iD, İrem Düzdar ${ }^{1}$ iD \\ ${ }^{1}$ Düzce Üniversitesi Endüstri Mühendisliği Bölümü, 81260 Düzce, TÜRKIYYE
}

Başvuru/Received: 01/10/2021

Kabul / Accepted: 30/12/2021

Çevrimiçi Basım / Published Online: 31/12/2021

Son Versiyon/Final Version: 31/12/2021

\begin{abstract}
Öz
Dünyamızı 2020 yılından itibaren etkisi altına alan Covid-19 ile insanlar yaşam mücadelesi vermektedir. Dünya Sağlık Örgütü tarafından "pandemi” kabul edilen bu dönemde hızlı bir şekilde yayılan virüsten, insanlar kendilerini ve çevrelerindekini korumayı amaçlamaktadırlar. İnsanlar kendini korurken işletmelerde dünya ekonomisinde yerlerini ve sürdürülebilirliklerini korumay amaçlamaktadırlar. Bu amaç doğrultusunda işletmeler çalışanlarından en yüksek düzeyde verim almalı ve bu verimi etkin bir şekilde kullanmalılardır. Çalışanlarını korumak için bu dönemde en önemli etkiye sahip olan işyeri içindeki çalışma ortamlarını analiz ederek ve iyileştirmeler yaparak başlamalılardır. Bu çalışmada, çalışma ortamlarında pandemi döneminde oluşan riskleri tespit ederek bu riskleri en aza indirme amacıyla Analitik Hiyerarşik Proses (AHP) yöntemi kullanılmaktadır. Kullanılan çok kriterli karar verme yöntemi ile risklerin işletme içerisinde etkili olduğu ağılık düzeyi belirlenir ve risk faktörleri önem derecelerine göre sıralanır. Yapılan çalışma sonucunda AHP yöntemi ile risk faktörleri değerlendirilmiş ve pandemi döneminde çalışma ortamlarını ve işletme verimliliğini etkileyen en büyük riskin psikolojik faktör olan çalışan motivasyonu, en düşük riskin ise ortam nemi kriteri olduğu belirlenmiştir. Bu çalışmanın işletmelere katkısı, güncel olarak etkisini devam ettiren Covid-19'un işletmelerde oluşan risk faktörlerinin ve boyutlarının tespit edilerek insan sağlığını tehdit eden unsurlara karşı önlem alınmasını ve zararlarını minimum düzeyde, verimlerini ise maksimum düzeyde tutulmasına katkı sağlar.
\end{abstract}

\section{Anahtar Kelimeler}

"Pandemi, Risk faktörleri, Çalışma Ortamlarl, Ergonomi, Analitik Hiyerarşik Proses"

\begin{abstract}
People are struggling for life with Covid-19, which has influenced our world since 2020. People aim to protect themselves and those around them from the virus, which spreads rapidly during this period, which is considered a "pandemic" by the World Health Organization. Business aims to protect its place and sustainability in the world economy, while people protect themselves. For this purpose, businesses should get the highest level of efficiency from their employees and use this efficiency effectively. They should start by analyzing and making improvements to the work environments within the workplace that have the most significant impact during this period to protect their employees. In this study, AHP method is used in order to minimize these risks by detecting the risks that occur during the pandemic period in working environments. The Multi-Criteria Decision-Making Method used determines the weight level at which risks are effective in the business, and the risk factors are sorted according to their degree of priority. As a result of the study, risk factors were evaluated using the AHP method and it was determined that the greatest risk affecting working environments and operating efficiency during the pandemic period was employee motivation, which is a psychological factor, and the lowest risk was ambient humidity. The contribution of this study to enterprises ensures that measures are taken against elements that threaten human health by identifying the risk factors and dimensions of Covid-19, which continue to have a current impact on enterprises. It contributes to keeping losses of enterprises at a minimum level and yields at a maximum level.
\end{abstract}

Key Words

"Pandemic, Risk Factors, Working Environments, Ergonomics, Analytic Hierarchical Process" 


\section{Giriş}

Günümüzde küresel dünyada çeşitli işletmeler ve organizasyonlar bulunmaktadır. Bu dünyada rekabet içinde bulunan işletmelerin temel amacı varlıklarını sürdürebilmek ve dünya koşullarında başarılı olabilmektir. İlerleyen teknoloji ile örgütsel devamlılığı sağlamak, verimliliği arttırmak, bireysel ve örgütsel performansı artırmak adına yeni yöntemler benimsenmektedir (Yamaç,2020). İşletmelerde çalışanların fiziki ve sosyal koşullarının tatmin edici olması çalışanların verimlilikleri üzerinde önemli rol oynamaktadır (Yamaç,2020). Ergonomi, iş ile insan arasında uyumu sağlar ve bu sayede verimliliği arttırır. Ergonomik açıdan kötü çalışma koşulları nedeniyle çalışanlarda oluşan motivasyon azalması ve yorgunluk sonucunda verimlilik düşüşleri gözlenmektedir (Hayta,2007). İşletme içerisinde performansı etkileyen en önemli nedenlerden birisi de çalışma koşullarıdır (Devi,2020). İş sağlı̆̆ı ve güvenliği açısından işletmeler değişen çevre koşullarına uyum sağlamalılardır. Çalışanlarının sağlığını göz önünde bulundurarak hazırlanmış işyeri ortamları ergonomik ve psikolojik açıdan sağlıklı olması üretimin kalitesini ve üretimin hızını arttırarak istenilen verimi sağlamaktadır. $\mathrm{Bu}$ nedenlerden dolayı işletmelerde verimliliği sağlayan ve devam ettiren en önemli unsurlardan bir tanesi işyeri çalışma ortamı ve buna bağlı olarak çalışan sağlığıdır.

2019 Aralık ayında Çin'in Vuhan kentinde ortaya çıkan Covid-19 virüsü, 2020 Mart ayından itibaren ülkemizi etkisi altına almıştır ve bundan kaynaklı olarak dünya da birçok alan değişime uğramıştır. Dünya Sağlık Örgüt'ü tarafından küresel salgın adı verilen "pandemi” ilan edilmiştir (Dünyada Covid-19 Pandemisi,2021). Virüsün bulaşma hızının dünya da ve ülkemizde yüksek ve kolay olması insanların kendilerini ve çevrelerindekileri korumaları için yeni yöntemler keşfetmelerine neden olmuştur. İnsanların kendilerini korumayı hedefledikleri gibi işletmelerde bu süreçte ekonomideki yerlerini ve varlıklarını korumayı hedeflemektedirler. Bu hedefler doğrultusunda birçok işletme pandemi döneminde çalışma şartlarını değiştirerek uzaktan çalışma modeline geçiş yapmıştır. Uzaktan çalışma modeline geçiş yapamayan ve çalışmalarını işletme içerisinde devam eden üretim işletmeleri gibi kuruluşlar Covid-19 virüs salgınına özgü riskleri belirleyerek ve işletme içerisinde bu riskler için tedbirler alınarak çalışmaya devam edilmesi gerekmektedir. Virüsün bulaşma riskinin yüksek olduğu yerlerden birisi de çalışma ortamlarıdır. Yukarıda belirttiğimiz üzere temas ve hava yolu ile bulaşan virüs kapalı ortam olan çalışma ortamlarında, ofislerde ve tesislerde çalışanlar üzerinde yüksek bulaşma oranına sahiptir. Çalışma ortamlarının insan sağlığı ve işletme verimliliği üzerine etkisine değinmiştik, pandemi sürecinde işletmeler bu olumsuz etkiyi engellemek amacıyla riskleri en aza indirerek bu ortamları korumalılardır.

\subsection{Amaç ve Kapsam}

Bu çalışmada ki amaç, pandemi döneminde çalışma ortamlarında oluşan riskleri çok kriterli karar verme yöntemi olan AHP kullanılarak sağlığımızla beraber işletme sürdürülebilirliğini etkileyen faktörlerin değerlendirilmesinin yapılmasıdır.

İnsanlık tarihi boyunca birçok salgın hastalık dünyayı ele geçirmiştir. 2020 yılı itibari ile Covid-19 virüsü hayatlarımıza girmiştir. Zor bir süreçten geçtiğimiz bu günlerde insanlar sağlığın önemini ve değerini daha iyi anlamış ve korumak için önlemler almışlardır. Kapalı ortam olan ve virüsün bulaşma olasılığının yüksek olduğu kabul edilen çalışma ortamlarında sağlığımızı etkileyen risk faktörleri bulunmaktadır. Her işletmenin pandemi döneminde korunma yöntemleri farklıdır. Uzaktan çalışma modeline geçiş, yarı kapasite ile çalışma modeline geçiş, çalışma saatlerinin kısaltılması ve yüz yüze çalışma modeline geçişler yapılmıştır. Yüz yüze çalışma modelini devam ettiren işletmeler için çalışanlarını etkileyen riskleri bulmak ve bu riskler için tedbirler almak önemli bir yere sahiptir. Bu önemden dolayı çalışmada çalışma ortamlardaki riskleri belirleyerek risklerin AHP yöntemiyle değerlendirilmesi ile risklerin öncelik dereceleri siralanmaktadır.

\section{2. Çalışma Ortamları ve Risk Faktörleri}

Ergonomi, işin gerçekleştirilme sırasında oluşan çevresel ve çalışma koşullarını inceleyen bilim dalıdır (Üçüncü,2005). Çalışma koşullarında çalışanları olumsuz etkileyen faktörler ve onların iyileştirilmesi ile ilgilenir. Çalışma koşulları işletmelerin önemli bir parçasıdır. Önemli bir parça etkin ve düzenli kullanılır ise işletmeler için büyük faydalar sağlanır. Kurumsal performans, çalışma ortamlarındaki ergonomik faktörlerin değerlendirilmesi ve iyileştirmelerin yapılması ile yüksek başarılar elde eder.

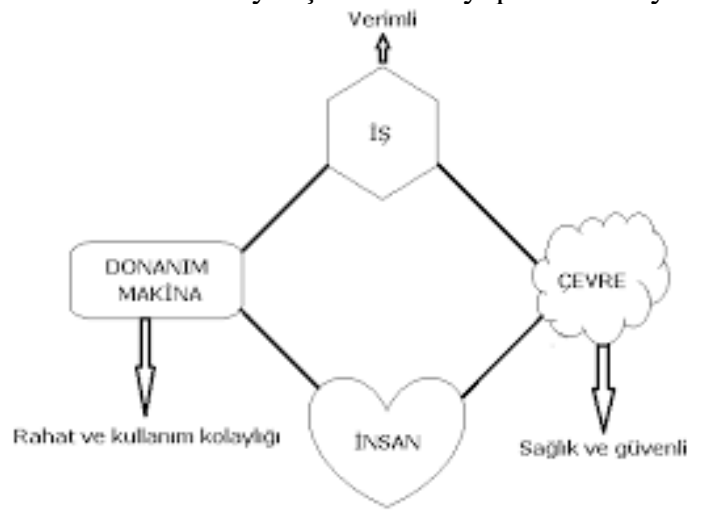

Şekil 1. Ergonominin Kapsamı (Üçüncü, 2005) 
Şekil 1. 'de ergonominin işletme içerisinde çalışma ortamı, iş, çevre ve insan faktörleri ile ilişkisi ifade edilmektedir. Ergonominin etkin kullanımı çalışma ortamını rahat ve kullanılabilir düzeye getirir. Çevre düzeni ile çalışan sağlığı sağlanır ve bu sayede işler ile çalışma performansını verimli hale getirilir.

\subsection{Pandemi Döneminde Çalışma Ortamları}

2020 yılı ile hayatımıza giren ve küresel salgın olan Covid-19 iş hayatında birçok değişime neden olmuştur. En büyük değiş̧imlerden biri de işletmelerin çalışma modellerini güncellemeleridir. Pandemi öncesinde beyaz yaka çalışanları baz alarak yapılan bir ankette Türkiye'de işletmetlerin \%45'i uzaktan çalışma modeli kullanılmaktadır. Pandemi döneminde bu oran \%71 tamamen uzaktan çalışma, \%19 ise dönüşümlü uzaktan çalışma modeli ile işletmelerde \%90 oranında uzaktan çalışma modeli uygulamaya başlamışlardır (Pandemi Sonrası Çalışma Hayatı Beklentilerinin Araştırılması, HR Dergi, 23 Haziran,2020). Uzaktan çalışma modeline geçiş yapamayan veya dönüşümlü uzaktan çalışma modelini kullanan \%29'luk işletmelerin bu süreçte dikkat etmesi gereken hususlar vardır. DSÖ ve Uluslararası Çalışma Örgütü(ILO) tarafından işletmeler için acil ve tamamlayıcı alınması gereken önlemler belirtilmiştir. İşletmelerin çalışanların sağlı̆̆ını tehlikeye atacak riskleri en aza indirmek amacıyla koruyucu önlemler alarak organizasyonlarına devam etmelilerdir.

Pandemi döneminde günlük hayatımız ve iş hayatımızda zorunlu kullanım haline gelen maske ve sosyal mesafe kuralları bütün işletmelerde uygulanır hale gelmektedir. Çalışanların koruyucu ekipman kullanıma özen gösterilmeli ve denetlenmelidir. Kişisel hijyene dikkat edilmeli ve fiziksel mesafe korunarak temas yoluyla bulaşma riski önlenmelidir. Pandemi döneminde çalışan sağlığını ve işletme verimliliğini etkileyecek çalışma ortamlarında ki risk faktörleri ve virüsun bulaşma seviyesi önlemler ile kontrol altına alınmalıdır.

\section{Literatür Taranması}

Literatür incelemesinde daha önceden yapılan benzer çalışmalar incelenmiştir. Yapılan araştırma sonucunda çalışma koşulları, ergonomi, işletme içerisinde değerlendirme ve risk çalışmaları incelenerek çalışmada kullanacağımız yöntem ve kriterler belirlenmiştir. Kapsamlı literatür taraması ile bir sonra ki aşamalar hakkında bilgi edinilmiş̧ir.

Ölmez vd., (2021) çalışmalarında, Covid-19 döneminde normalleşme süreci boyunca işe dönüş kapsamında ofis çalışmalarında oluşan risklerin değerlendirilmesini ve incelenmesini amaçlanmıştır. Balık kılçı̆̆ı yönteminin kullanıldığ çalışmada altı faktörün çalışma ortamındaki risklerinin yüksek olduğu belirlenmiştir.

Akbal ve Akbal (2020) çalışmalarında, Covid-19 pandemi döneminde yüzyüze eğitimden farklı olarak eğitimde gerçekleşen yeni sistemin öğrenci bakış açısına göre yaşanan en önemli sorunun tespit edilmesi amaçlanmıştır. AHP yönteminin kullanıldığı çalışmada eğitim sürecinden ortaya çıkan en önemli sorunun fiziki koşullar olduğu sonucuna varılmıştır

Işık ve Dağsuyu (2020) çalışmalarında, üretim yapan bir işletmenin departmanlarında ki ergonomik yapıların farklılıklarından ortaya çıkan ihtiyaçlar mevcuttur. Departmanların ergonomik değerlendirilmesini AHP yöntemi ile yapmıştırlar. Ergonomik faktörlerin önem seviyeleri değerlendirilirken çevresel, fiziksel ve psikolojik kriterler göz önüne alınmıştır. Çalışmada ergonomik faktörlerin en önemli üretim departmanlarında olduğu ortaya çıkmıştır.

Pirinççi ve Özdemir Güngör (2019), çalı̧̧an motivasyonunu etkileyen faktörlerin AHP yöntemi ile değerlendirilmesinin amaçlandığ 1 çalışma da İzmir'de bulunan ilaç satı̧s temsilcilerin iş motivasyonları Sosyo-ekonomik, örgütsel ve yönetsel ve psiko-sosyal boyutta değerlendirilmiştir. Çalışma sonucunda sosya-ekonomik boyutun çalışan motivasyonunda en önemli kriter olduğu belirlenmiştir.

Büyükselçuk vd.,(2005), çalışma koşullarını ve çalışan memnuniyetini değerlendirmeyi amaçladıkları çalışmada otomotiv sektörüne ait bir işletmede AHP yöntemi kullanarak değerlendirme yapmıştırlar. Çalışma koşullarını fiziksel kriterler ile değerlendirerek işletme için verimliliği etkileyen faktörler belirlenmiştir. Çalışma sonucunda fiziksel çalışma koşullarından en çok öneme 1şık kriterinin sahip olduğu belirlenmiş̧ir .

Daha önce yapılan çalışmalar incelendiğinde AHP yönteminin birçok çalışmada kullanıldı̆̆g görülmüştür. Ergonomi içinde kullanılan AHP yöntemi çalışmamızda Pandemi döneminide ele alarak diğer çalışmalara göre farklı bir ilerleyiş gerçekleştirmiştir.

\section{1. Çalışmada Ele Alınan Risk Faktörleri}

\section{Fiziksel (Çevresel) Risk Faktörleri}

Fiziksel risk faktörleri her çalışma ortamında ortaya çıkan gürültü, ergonomik çalışma durumu, aydınlatma, titreşim ve termal konfor şartlarını ifade eden bir ana kriterdir (Kısa,2014).

Fiziksel(çevresel) Risk Faktörleri alt kriterleri;

- Ortak alanlar: İ̧̧letme içerisinde çalışanlar tarafından gün içerisinde kullanılan alanları ifade eder. Pandemi döneminde işletmeler için de risk teşkil eden bir faktördür bunun sebebi temas alanlarının birbirleri ile etkileşimidir (Ölmez vd.,2021). Örneğin, lavabo.

- Ekipman kullanımı: Ofis ve üretim alanlarında çalı̧̧anların yaptıkları işler sırasında yardım aldıkları malzemelerdir. Ekipmanların kişiye özel olmasıyla birlikte toplu kullanım durumları da vardır (Kısa,2014). 
- Havalandırma: Çalışanların sağlıklı bir şekilde yüksek tempolar da çalışmalarının en önemli etkeni çalışma ortamlarındaki havanın temiz olmasıdır. Covid-19 virüsünün solunum yoluyla bulaşmasından dolayı kapalı çalışma ortamları çalışanlar için büyük risk teşkil etmektedir.

- Ortam nemi: Nem oranı yüksek ise çalışanların burun ve boğazları dolar ve çalışanı bunaltır. Çok kuru hava içeren çalışma ortamları da, çalışanların burun içlerini ve soluk borusunu kurutur ve sık sık su içme ihtiyacı yaratırlar (Büyükselçuk vd.,2005). Bu durumdan kaynaklı uygun nem koşullarının olmazsa çalışanların hasta olma riskleri artar ve pandemi döneminde kapalı ortamlardaki havanın taze ve sağlıklı olması gerekmektedir.

- Sosyal mesafe: Çalışma ortamında çalışanlar, çalışma koşulları ve çalışma masalarının arasında belirli bir mesafe olmasını ifade eder (Ölmez vd.,2021). Covid-19'un yayılmasını önlemek için alınan 1,5 metre sosyal mesafe fiziksel temas kuralı tüm işletmelerde kullanılmalıdır (TC. Aile, Çalışma ve Sosyal Hizmetler Bakanlığı Covid-19 Döneminde Ortak Alanlar Kullanım Alanları Rehberi)

Tablo 1. Kullanılan Kriterler

\begin{tabular}{cl}
\hline \multicolumn{1}{c}{ ANA KRITERLER } & \multicolumn{1}{c}{ ALT KRITERLER } \\
\hline \multirow{3}{*}{ Fiziksel (Çevresel) Risk Faktörleri } & Ortak Alanlar \\
& Ekipman Kullanımı \\
& Havalandırma \\
& Ortam Nemliliği \\
& Sosyal Mesafe \\
& Koruyucu Ekipman Kullanımı \\
& İnsan Yaşamı \\
& İş Yoğunluğu \\
Psikolojik Risk Faktörleri & Kişisel Hijyen \\
& Çalışma Motivasyonu \\
& Temizlik ve Bakım \\
& Çalışma Saati \\
& Çalışan Sağlık Güvencesi \\
& Kapasite \\
\hline
\end{tabular}

\section{Psikolojik Risk Faktörleri}

Psikolojik faktörler sosyal, kültürel ve fiziksel ortam içerisinde oluşan ve bireyi etkileyen problemlerdir (Işıłk ve Dağsuyu,2020). Çalışan psikolojisinin olumsuz yönde etkilenmesi çalışanın ve işletmenin performansını düşürür. Pandemi dönemi insanları psikolojik yönden etkileyen zor bir süreç olmaktadır.

Psikolojik Risk Faktörlerinin alt kriterleri;

- İnsan yaşamı: İnsanların çalışma ortamları dışında bulundukları özel yaşamları mevcuttur. İnsanlar yaşamları boyunca psikolojik olarak birçok konudan etkilenir. İnsanlar pandemi dönemin de sosyal ve çalışma hayatlarını kontrol altına almaya çalışırken kendilerini çok zorladıklarını düşünme durumlarından kendilerinden alınan verimleri azaltırlar (Ölmez vd.,2021).

- Kişisel hijyen: İnsanın kendi sağlı̆̆ı ve çevresinin sağlığı için temizlik kurallarına dikkat etmesidir. Düzenli kişisel hijyen ile oluşan riskleri minimize edilebilebilir (Ölmez vd.,2021). Bireyler hijyenlerine dikkat ederken bu durumun aşırıya kaçması durumunda kendilerini yıpratırlar.

- Koruyucu ekipman kullanımı: Çalışma ortamlarında zorunlu hale getirilen maske kullanımıdır. Aynı zamanda işletmeler isteğe bağlı siperlik, eldiven gibi ekipmanlarıda zorunlu hale getirmiştir. Bu zorunluluk durumu ile maske kullanımının nefes darlı̆ğ gibi sorunları ortaya çıkartmıştır ve insanlar arasında psikolojik sorunlar oluşturmaktadır. Kullanılmama durumunda ise insan ve ortam açısından büyük riskler oluşur (Ateş,2020).

- İş yoğunluğu: Bir çıktı elde etmek için ve süreçlerin kesintisiz devam etmesini sağlamak amacıyla çalışanlar yoğun tempolar ile görevlerini yerine getirmelidir. Bu dönemde yaşanılan çalışma ortamları ve çalışma şekillerindeki değişiklikler ile ertelenilen, biriken işler mevcuttur daha sonradan bu işlerin yapılabilmesi için ekstra emek harcanmaktadır. Harcanılan bu fazla enerji ile çalışanların bünyelerinin zayıf düşmesiyle birlikte virüse yakalanma riskleri artar (Pandemi Sonrası Çalışma Hayatı Beklentilerinin Araştırılması, HR Dergi, 23 Haziran 2020).

- Çalışan motivasyonu: Motivasyon, bireylerin amaçlarını ve görevlerini gerçekleştirirken psikolojik olarak kendilerini iyi hissederek enerjik ve verimli hareket etmelerini sağlar. Motivasyonu sağlayan faktörler insanların ihtiyaçlarının sağlanması ile gerçekleştirilir (Pirinççi ve Özdemir Güngör 2019). Pandemi dönemini zor bir süreç olduğu için çalışanların motivasyonlarını kaybetme, ortam verimliliğinin ve işletme verimliliğinin düşmesi gibi riskler ortaya çıkmaktadır (Pandemi Sonrası Çalışma Hayatı Beklentilerinin Araştırılması, HR Dergi, 23 Haziran 2020).

\section{Yönetimsel Risk Faktörleri}

İşletme yönetimi tarafından hedefler doğrultusunda sürdürülebilirliklerin devam etmesi için dikkat edilmesi gereken noktalar vardır. 
Çalışma ortamlarında fiziksel ve psikolojik risk faktörleri gibi yönetimden kaynaklanan problemlerde işletme için risk teşkil etmektedir.

Yönetimsel Risk Faktörlerinin alt kriterleri;

- Temizlik ve bakım: Yönetim tarafından çalışan sağlığını koruyarak çalışan kaybetmek ve işletme verimliliğini düşürmemek ana amaçlardandır. Temizlik işlemi, yüzeyleri bakterileri ve patojenlerden arındırılmasına yardımcı olur bir dezenfeksiyon işleminde önemli bir ilk adımdır (TC. Aile, Çalışma ve Sosyal Hizmetler Bakanlığı Covid-19 Döneminde Ortak Alanlar Kullanım Alanları Rehberi). İ̧̧letme yönetimi çalışma ortamlarının temizliğini düzenli yapılması için plan yapmalı ve ortamı dezenfekte ederek çalışan sağlığı için ortaya çıkan riskleri ortadan kaldırmalıdır (Hayta,2007).

- Çalışma saati: Yönetim tarafından çok çalışma çok verimlilik düşüncesi vardır fakat kapalı ortamlarda uzun süreli çalışma üretkenlik ve verimlilik azaltmaktadır (Hayta,2007). Çalışma saatlerinin uzun olduğu işletmelerde aynı ortamda bulunup aynı havayı soluyan insanların bulunması risk taşımaktadır. Yönetim tarafından belirlenen çalışma saatleri pandemi döneminde önemli bir kriterdir (Hayta,2007).

- Çalışan sağlık güvencesi: Yönetim çalışanlarına sağlık konusunda yardımcı olarak ve koruyarak çalışan yönetim arası güven seviyesini güçlendirirler aynı zamanda çalışanlarından alacakları verimi arttırırlar.

- Kapasite: Aynı ortamda bulunan insan sayısının sınırıdır. Yönetim tarafından sosyal mesafe riskine uyulması için belirlenmesi gereken bir kriterdir (TC. AİLE ÇALIŞMA VE SOSYAL HİZMETLER BAKANLIĞI, YENİ KORONAVİÜSS SALGINI KAPSAMINDA IŞS SAĞLIĞI VE GÜVENLIĞİ PROFESYONELLERININ İŞYERLERINNDE ALDIRACAĞI TEDBİRLER,2021)

Aynı kapalı ortam içerisindeki çalışan sayısının yüksek olması Covid-19 virüsünün bulaşma olasılığını arttırıcı bir etkendir. Yönetim bu riski düşürmek amacıyla çalışma ortamlarındaki kişi sayısını sınırlanmalıdır.

\section{Yöntem}

Çalışma kapsamındaki amaç işletmelerde pandemi döneminde çalı̧ma ortamlarında oluşan risk faktörlerinin belirlenmesi ve değerlendirilmesidir. Belirlenen risk faktörlerin değerlendirilirken AHP yöntemi kullanılmıştır. İşletme yönetimi bu süreçte en az zarar ile ekonomide ki yerlerini korumayı amaçladıklarından bu risk faktörleri tespit edilip, tedbirlerin alınması büyük bir fayda sağlamaktadır. Risk faktörlerini oluşturan kriterler pandemi dönemini ele alınarak belirlenmiştir. Sözel olan kriterler AHP yöntemiyle ikili matrisler şeklinde ağırlıklandırılıp karşılaştırılır ve daha sonra bu riskler öncelik sıralarına göre sıralanır. Çok Kriterli Karar Verme yöntemleri arasında bulunan AHP yöntemi ele alınan problemde en önemli risk faktörlerini öncelik sırasını ortaya çıkarmak olduğu için bu yöntem seçilmiştir.

Çalışmada etik kurul onayı alınması gerekmemiş̧ir. Bu bölümde çalışmada kullanılacak yöntem ve uygulama aşamaları hakkında bilgi verilmiştir.

\subsection{Analitik Hiyerarşi Prosesi(AHP)}

Tüm insanlar hayatları boyunca birer karar vericidir ve yaptıkları her eylemi, vermiş oldukları kararlar neticesinde gerçekleştirirler. Elde edilen bilgiler de olayı benimsemelerine ve daha iyi çözümleme yaparak değerlendirmelerini sağlar ki bu da doğru çözüm kararlar vermeleri için uygun bir altyapı oluşturur (Vassilev ve Vassileva,2005). Çok kriterli karar verme problemlerindeki temel sorun, çeşitli alternatifler arasından birden çok kriter ile seçim yapabilmek için ağırlık, önem veya üstünlük belirlemektir. Belirtilen bu sorunu çözmede AHP etkin olarak kullanılan bir ÇKKV yöntemidir. AHP'de, karar verme süreçlerinde çözüm elde etmek için karar vericilerin öznel ve nesnel düşünceleri dâhil edilmektedir (Gülenç ve Bilgin,2010)

Analitik Hiyerarşi Prosesi, 1968 yılında ilk olarak Myers ve Alpert ikilisi tarafından ortaya atılmış ve 1977'de Profesör Thomas Lorie Saaty ile bir model olarak geliştirilerek karar verme problemlerinin çözümünde kullanılabilir hale getirilmiştir (Yaralığlu,2001). AHP yöntemi karar alma sürecinde grup ve bireyin kararlarını da göz önüne alan, nitel ve nicel değişkenleri bir arada değerlendiren matematiksel bir yöntemdir. Bu durum AHP'yi diğer karar verme yöntemlerine kıyasla daha güçlü kılmaktadır. Karar vericiler problemde birbirlerinden farklı olarak değerlendirmelerini yapabilir, daha sonra değerlendirmelerin geometrik ortalamaları alınarak ortak karşılaştırma matrisleri oluşturulur. Bu uygulama çeşidinde dikkat edilmesi gereken en önemli kısım, her bir karar vericinin değerlendirmeleri ile oluşturulan karşılaştırma matrislerinin ayrı ayrı tutarlılıklarının incelenmesidir. Daha sonra geometrik ortalamalar alınarak elde edilen bütünleştirilmiş matrislerin tutarlılıkları incelenir (Önder ve Önder,2015). Değerlerin birbirlerine bağlı olarak artış veya azalış gösterdiği durumlarda bu değişimin hızı geometrik ortalama ile doğru sonuçlar verir (Temel İstatistik Ders Notları, On Dokuz Mayız Üniversitesi,2018).

AHP yönteminin uygulama aşamaları 6 adımdan oluşmaktadır.

\section{i. Adım Problemin Tanımlanması}

Problemi en iyi şekilde tanımlanmalıdır. Karar için gerekli olan kriterler belirlenir. Seçilmiş olan karar problemin ana amacımıza ve kullanılacak olduğumuz modele de uygun olmalıdır.

\section{ii. Adım Hiyerarşik Yapının Oluşturulması}


Karar amacı ile en üstten başlayarak karar hiyerarşisi oluşturulur (Gülenç ve Bilgin,2010). Hiyerarşik yapıda hedefin altında ise ana kriterler ve alt kriterler bulunur. Hiyerarşik yapının en altında ise alternatifler yer almaktadır. Hiyerarşinin aşama sayısı, problemin karmaşıklık düzeyine göre şekillenmektedir.

\section{iii. Adım İkili karşılaştırma matrislerinin oluşturulması ve ağırlıkların belirlenmesi}

Hiyerarşik yapı elde edildikten sonra kriterler problemin karar vericileri tarafından ikili karşılaştırmaları yapılmaktadır. İkili karşılaştırma karar matrisleri temelde alternatiflerin karşılaştııılması ve problemdeki kriterlerin kendi aralarında karşılaştırılmasını ile oluşturulur (Dağdeviren ve Eren,2001). A kriterinin B kriteri ile karşılaştırılmasında A kriterinin önem derecesi a ise B kriterinin önem derecesi 1/a olmaktadır (Turgut,2015).

Saaty (2008) tarafından geliştirilen Tablo 2'de belirtilen 1 ile 9 arasında değerler alan bir önem derecesi ölçeği kullanılarak, ana kriterler, varsa alt kriterler ve son olarak tüm kriterler dikkate alınarak kriterlere göre alternatiflerin karşılaştırıldığı matrisler oluşturulur. Şekil 2'de belirtildiği üzere karşılaştırma matrisleri köşegen elemanları 1 olan bir kare matristir.

Tablo 2. İkili Karşılaştırma Önem Dereceleri (Saaty ,2008)

\begin{tabular}{cll}
\hline $\begin{array}{c}\text { Önem } \\
\text { Derecesi }\end{array}$ & \multicolumn{1}{c}{ Tanım } & \multicolumn{1}{c}{ Açıklama } \\
\hline 1 & Eşit önemli & İki seçenek de eşit derecede katkıda \\
3 & Orta derecede önemli & Tecrübe ve yargı bir kriteri diğerine karşı biraz üstün kılmaktadır. \\
5 & Kuvvetli derecede & Tecrübe ve yargı bir kriteri diğerine karşı oldukça üstün kılmaktadır. \\
7 & Çok kuvvetli derecede & Bir kriter diğerine göre üstün sayılmıs ve bu üstünlük uygulamada göze çarpmaktadır. \\
9 & Kesin önemli & Bir kriterin diğerinden üstün olduğunu gösteren kanıt çok büyük güvenilirliğe sahip \\
$2,4,6,8$ & Ara değerler & Uzlaşma gerektiğinde kullanılmak üzere iki ardışık yargı arasındaki değerler \\
\hline
\end{tabular}

$$
\begin{aligned}
& \begin{array}{llllll}
C_{1} & C_{2} & \ldots & C_{n} & \mathrm{n}=\text { değerlendirilecek kriter sayısı }
\end{array}
\end{aligned}
$$

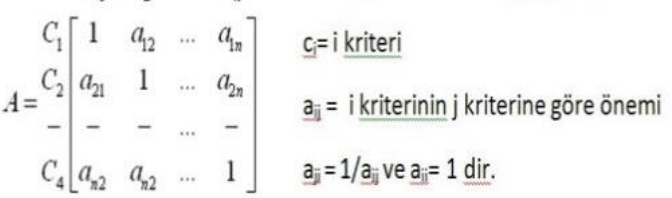

\section{Şekil 2. Matris Düzeni}

\section{iv. Adım Öncelik Vektörünün Hesaplanması}

Karşılaştırma matrisinin her bir sütunundaki eleman, sütunların toplam değerine bölünerek normalize edilmiş matris bulunur. Matrisin her satırının ortalaması alınarak "Öncelikler Vektörü" bulunur. Öncelikler vektörünün hesaplanmasından sonra "Tüm Öncelikler Matrisi” oluşturulması için elde edilen öncelikler vektörü en başta oluşturulan karşılaştırma matrisi ile çarpılarak, karşılaştırma matrisini dikkate alır (Baysal,2018).

\section{v. Adım Tutarlılık Oranının Hesaplanması}

Karşılaştırma matrislerinin tamamlanmasından sonra öncelik vektörü hesaplanır. Öncelik vektörü hesaplanırken, normalize edilen matrisin her bir satır toplamı, matrisin dizeyine bölünerek ortalamaları bulunur. Elde edilen bu değerler her bir kriter için hesaplanan önem ağırlıklarıdır. $\mathrm{Bu}$ ağırlıklar, problemin öncelik vektörünü oluşturur. Karşılaştırmaların ve önceliklerin belirlenmesinden sonra tutarlılık oranı belirlenir. İkili karşılaştırma değerlendirmeleri sonucu oluşan matrisin tutarlı olup olmadığını belirleyebilmek için birçok yöntemden bir tanesi olan "Tutarlılık İndeksi (CI)" adı verilen katsayının hesaplanması gerekmektedir (Açık Ders, 2011).

Karşılaştırma matrislerinin tutarlılık oranı 0,10’dan küçükse yapılan karar verme işlemi tutarlıdır.

$$
C I=\lambda \max /(n-1)
$$

CI: Tutarlılık Göstergesi

$\lambda$ max: Öncelikler matrisinin her bir değeri, öncelikler vektörü değerlerine bölünerek, elde edilen yeni matris elemanlarının ortalamas1 alınarak elde edilir (Saaty, 2008).

n: Matrisin boyutu

CI bulunduktan sonra tutarlılık oranı (CR) şu şekilde hesaplanır; 
$C R=\frac{C I(\text { Tutarllllk Göstergesi })}{R I(\text { Rassalllk Göstergesi })}$

Tablo 3. Rassal Göstergeler (Saaty, 2008)

\begin{tabular}{|c|c|c|c|c|c|c|c|c|c|c|c|c|c|c|c|}
\hline $\mathrm{n}$ & 1 & 2 & 3 & 4 & 5 & 6 & 7 & 8 & 9 & 10 & 11 & 12 & 13 & 14 & 15 \\
\hline RI & 0,00 & 0,00 & 0,58 & 0,90 & 1,12 & 1,24 & 1,32 & 1,41 & 1,45 & 1,49 & 1,51 & 1,48 & 1,56 & 1,57 & 1,59 \\
\hline
\end{tabular}

\section{vi. Adım Nihai Kriter Ağırlıklarının Değerlendirilmesi}

Belirlenen tutarlılık değerleri ile çalışmanın bir sonraki aşaması kriter ağırlıklarının hesaplanması ve sıralamasıdır. Elde edilen ana kriter öncelik vektörü (W) ile alt kriterlere ait öncelik vektörleri(W) çarpılarak kriter ağılıkları elde edilir. Kriter ağırlıkları bulunarak siralama yapilır.

\section{2. Çalışma Modeli}

Bu çalışmada AHP yöntemi kullanılacaktır. Yöntemin belirlenmesi ile birlikte yöntemi ele aldığımız probleme uyarlayarak Şekil 3'de belirtildiği üzere AHP yöntemi ile yapılacak ana aşamalar belirtilmiştir.

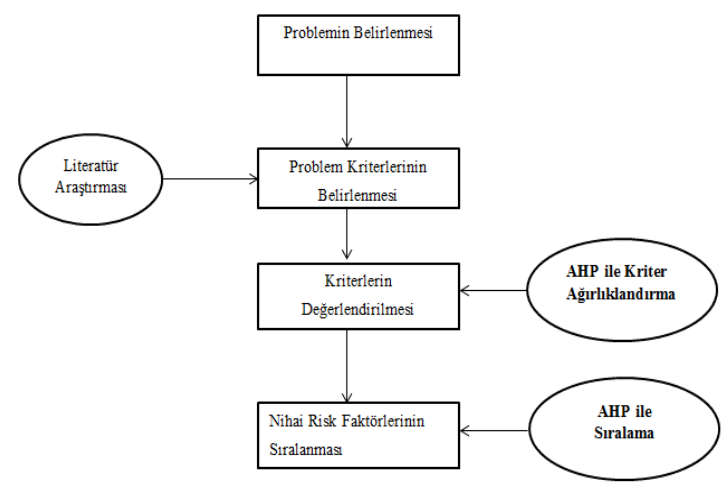

Şekil 3. Amaçlanan AHP Yöntemi Aşamaları

Çalışmada ele aldığımız Analitik Hiyerarşi Prosesi yönteminin başarılı sonuçlar elde etmesi için ilk aşama olarak hedefimizin belirlenmesi gerekmektedir.

Çalışmadaki amaç, zorlu bir süreç olan pandemi döneminde işletmelerdeki çalışma ortamlarında oluşan risk faktörlerinin belirlenerek AHP yöntemi ile kriter ağırlıklandırmalarının yapılması ve risk faktörlerinin öncelik derecelerine göre sıralanmasıdır. Kullanılan kriterler çalışma ortamlarının ergonomik açıdan inceleyen literatürlerin taraması ile belirlenmiştir. Literatür de en çok kullanılan risk faktörleri tercih edilmiştir. Çalışmada kullanılan kriterler; üç ana kriter ve her bir ana kriterin alt kriterleri ile on dört alt kriter vardır. Kriterlerin belirlenmesinden sonra ağırlıklandırılması için AHP yöntemi hiyerarşik yapısı oluşturulmuştur. En üstte çalışmada ulaşılması hedeflenen durum vardır. İkinci seviyede çalışmada ele alınan ana kriterler bulunmaktadır. Üçüncü seviyede her bir ana kritere ait alt kriterler bulunmaktadır.

Çalışmadaki hedef çalışma ortamlarındaki en öncelikli riskin belirlenmesidir. Çalışmada üç ana kriter vardır; Fiziksel(çevresel) Risk Faktörleri, Psikolojik Risk Faktörleri ve Yönetimsel Risk Faktörleri kriterleridir.

Şekil 4'de gösterildiği üzere SuperDecision paket programı ile problemin AHP modeli oluşturulur ve kriterlerin birbirleri ile bağlantıları ifade edilir. Üç seviyeye sahip hiyerarşik modelin hedef kümesinde çalışma ortamlarında öncelikli riskin belirlenmesi amacı bulunmaktadır. Hedef kümesi ikinci seviye olan ana kriterler kümesi ile bağlantılıdır. Ana kriterler kümesinde fiziksel risk faktörleri, psikolojik risk faktörleri ve yönetimsel risk faktörleri bulunmaktadır. Üçüncü seviyede ana kriterler kümesi her bir kriterin alt kriterinin bulunduğu ana kümeler ile bağlantı oluşturmaktadır. 


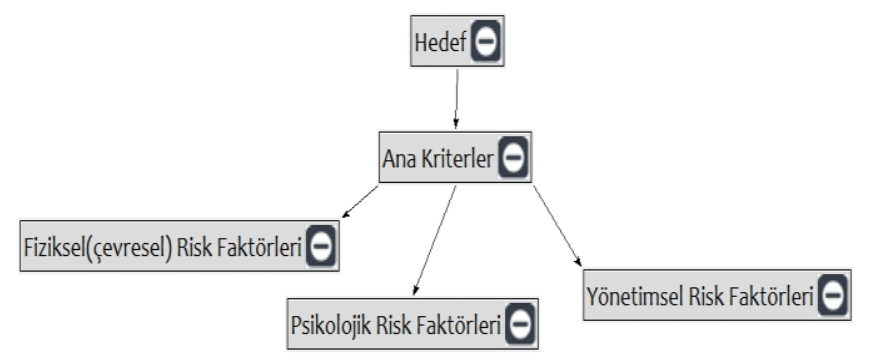

\section{Şekil 4. SuperDecision Üzerinde AHP Modeli}

Tablo 4 'de AHP hiyerarşik modeline ait hedef, ana kriterler ve alt kriterlerin ilişkisini gösteren matris bulunmaktadır. A hedef, B kriterler, $\mathrm{C}$ alt kriterleri ifade etmektedir. Hedef, kriterlere bağlıdır. Ana kriterler arasında ilişki bulunmaktadır ve ikili karşılaştırmalar yapılmaktadır. Ana kriterlerine göre gruplandırılan alt kriterlerde kendi ana kriterine ait kriterler ile karşılaştırmalar yapılmaktadır.

Tablo 4. İlişki Matrisi

\begin{tabular}{lccc}
\hline & Hedef & Ana Kriterler & Alt Kriterler \\
\hline Hedef & 0 & 0 & 0 \\
Ana Kriterler & A & B & 0 \\
Alt Kriterler & 0 & C & 0 \\
\hline
\end{tabular}

SuperDecision programı üzerinden oluşturulan AHP modelinin daha sade ve açıklayıcı modeli Şekil 5'de bulunmaktadır. Şekil 5 üzerinde hiyerarşik yapının seviyesi ve kriterler ile bağlantıları görülmektedir.

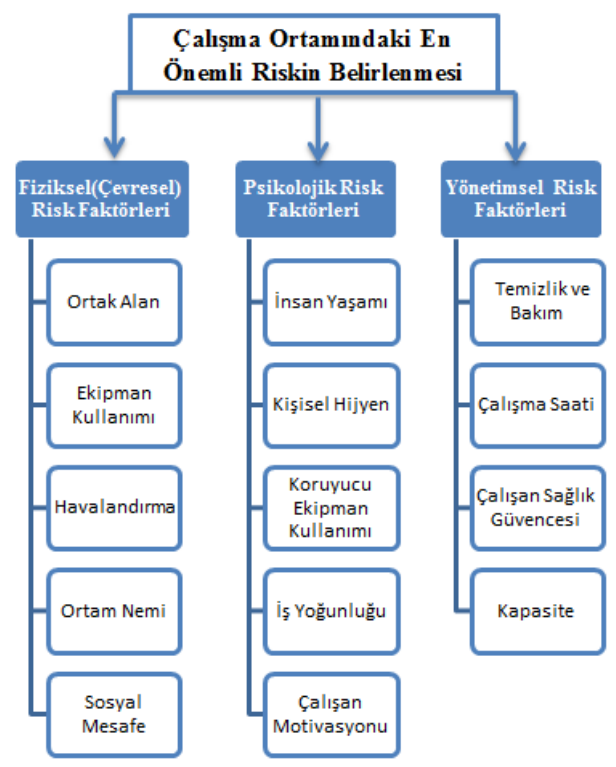

Şekil 5. Çalışma Ortamlarındaki En Önemli Riskin Belirlenmesi Hedefi Hiyerarşik Yapısı

\subsection{Verilerin Elde Edilmesi}

Çalışması kapsamında ana ve alt kriterlerin belirlenmesinden sonra AHP yönteminin ana aşamalarından olan kriterlerin değerlendirilmesi için işletmelerde çalışmakta olan üç uzmana danışılmıştır. Belirlenen kriterlerin açıklamaları ve değerlendirme yaparken dikkat edilmesi gereken hususlar iletilmiştir. Kriterlerin birbirleri ile bağlantıları ifade edilerek değerlendirmelerde tutarsızlık meydana gelmesi önlenmiştir. Excel üzerinden pandemi dönemini göz önüne alarak çalışma koşullarında yaşadıkları zorlukları ifade eden risklerin ikili karşılaştırma anketleri oluşturulmuştur ve ana kriterlerin değerlendirilmesinden sonra alt kriterlerin ikili karşılaştırılmasının yapılması istenmiştir. Yapılan değerlendirme sonuçlarının elde edilmesi ile karşılaştırma matrisleri oluşturulmuştur. 


\subsection{Uygulama}

Bu bölümde teorik bilgileri ifade edilen çözüm yönteminin uygulama aşamaları ve elde edilen verileri ele alınmaktadır. Problem çözümü için çalışmanın hedefini belirleyerek ve bu hedef doğrultusunda kullanılacak yöntemleri en iyi şekilde benimseyerek faydalı sonuçlar elde etmektir.

Uygulamanın ilk kısmında AHP yöntemi ile çalışma ortamlarında oluşan risk faktörlerinin belirlenip kriter ağırlıkları elde edilmiştir. Literatür taraması sonucu elde edilen kriterler Saaty tarafından önerilen 1-9 önem skalası kullanılarak uzman görüşlerin ikili karşılaştırma matrisleri elde edilmiştir. Çalışmanın devamında ikili karşılaştırma matrisleri ile karar vericilerin her biri için ana kriter ve alt kriterlere göre tutarlılık oranı hesaplanmıştır. Karar vericilerin cevaplarının Tutarlılık oranları $\mathrm{CR}<0,1$ ile tutarlı kabul edilmiştir.

AHP metodunda birden fazla karar vericinin olduğu durumlarda karar vericilerin birbirlerinden ayrı olarak değerlendirdiği sonuçların geometrik ortalamaları alınır ve ortak bir matris oluşturulur. Ana ve alt kriterler için oluşturulan bütünleştirilmiş matrisin tutarlılık oranını hesaplanmalı ve $\mathrm{CR}<0,1$ olmalıdır. Çalışmada karar vericile birden çok olduğu için ana ve alt kriterlerin bütünleştirilmiş matrisleri SuperDecision paket programı yardımı ile kriter ağırlıkları hesaplanmıştır. Belirlenen kriter ağırlıkları sıralanarak pandemi döneminde işletmeleri etkileyen risk faktörlerinin öncelik sıraları belirlenmiştir.

Tablo 5'de ana kriterlere ait öncelik değerleri ve sıralamaları bulunmaktadır. Ana kriterlerlerden Psikolojik Risk Faktörü 0,6915 değeri ile en öncelikli kriter olarak belirlenmiştir. Psikolojik Risk Faktörleri sadece insanın çalışma alanındaki verimliliğini değil aynı zamanda kişisel sorunlarını, aile ve sosyal hayatınıda olumsuz etkileyen bir risk faktörüdür. AHP yöntemi ile Fiziksel Risk Faktörü 0,1796 değerini olarak pandemi döneminde çalışma ortamlarını etkileyen ikinci kriterdir. Günümüzü etkisi altına alan bu süreçte işletmelerin çalışma ortamlarını Yönetimsel Risk Faktörü 0,1288 değeri ile ana kriterler arasında en az etkileyen risk faktörü olarak belirlenmiştir.

Tablo 5. Ana Kriterlerin Öncelik Değerleri

\begin{tabular}{lc}
\hline \multicolumn{1}{c}{ ANA KRITERLER } & A ĞIRLIK \\
\hline Psikolojik Risk Faktörleri & 0,6915 \\
Fiziksel Risk Faktörleri & 0,1796 \\
Yönetimsel Risk Faktörleri & 0,1288 \\
\hline
\end{tabular}

Tablo 6'da alt kriterlerin her birinin öncelik değerleri bulunmaktadır. Risk faktörleri ana kriterlerine göre gruplandırılmıştır. Her ana kritere ait alt kriterlerde öncelik değerleri yüksek olandan düşük olana göre sıralanmıştır

Tablo 6. Alt Kriterlerin Öncelik Değerleri

\begin{tabular}{clc}
\hline ANA KRITERLER & \multicolumn{1}{c}{ ALT KRITERLER } & Ăğırlık \\
\hline \multirow{3}{*}{ Fiziksel (Çevresel) Risk Faktörleri } & Sosyal Mesafe & 0,3367 \\
& Ortak Alanlar & 0,2094 \\
& Havalandırma & 0,2074 \\
& Ekipman Kullanımı & 0,1733 \\
& Ortam Nemliliği & 0,0732 \\
& Çalışma Motivasyonu & 0,2877 \\
& Kişisel Hijyen & 0,2699 \\
\multirow{2}{*}{ Psikolojik Risk Faktörleri } & İş Yoğunluğu & 0,2043 \\
& İnsan Yaşamı & 0,1204 \\
& Koruyucu Ekipman Kullanımı & 0,1177 \\
& Temizlik ve Bakım & 0,3248 \\
& Çalışan Sağlık Güvencesi & 0,2966 \\
Yönetimsel Risk Faktörleri & Çalışma Saati & 0,2171 \\
& Kapasite & 0,1615 \\
\hline
\end{tabular}

Çalışmanın son aşamasında elde edilen alt kriterlere ait öncelik değerleri ile ait oldukları ana kriterlerinin çarpma işlemi yapılarak kriter ağırlıklarının bulunmasıdır. W öncelik vektörlerini ifade etmektedir.

Elde edilen kriter ağırlıkları ile nihai sıralama yaparak problemde amaçlanan çözüme kavuşacaktır. Tablo 5 'de belirtilen ana kriterlere ait öncelik değerleri ile Tablo 6`da belirtilen alt kriterlerin öncelik değerleri çarpılarak kriter ağırlıkları Tablo 7'de elde edilmiştir.

$\mathrm{W}_{\text {alt kriter }} \mathrm{X} \mathrm{W}_{\text {ana kriter }}$ 
Tablo 7. Alt Kriterlerin Ağılık Değerleri ve Nihai Sıralama

\begin{tabular}{ccr}
\hline Sıralama & ALT KRİTERLER & SONUÇ \\
\hline 1 & Çalışma Motivasyonu & 0,19895 \\
2 & Kişisel Hijyen & 0,18664 \\
3 & İş Yoğunluğu & 0,14127 \\
4 & İnsan Yaşamı & 0,08326 \\
5 & Koruyucu Ekipman Kullanımı & 0,08139 \\
6 & Sosyal Mesafe & 0,06047 \\
7 & Temizlik ve Bakım & 0,04183 \\
8 & Çalışan Sağlık Güvencesi & 0,03820 \\
9 & Ortak Alanlar & 0,03761 \\
10 & Havalandırma & 0,03725 \\
11 & Ekipman Kullanımı & 0,03112 \\
12 & Çalışma Saati & 0,02796 \\
13 & Kapasite & 0,02080 \\
14 & Ortam Nemliliği & 0,01315 \\
\hline
\end{tabular}

Alt kriterlerin ağırlıklarının belirlenmesi ile en yüksek ağırlık değerine sahip kriter 0,19895 değerine sahip "Çalışan Motivasyonu" dur. Daha sonra ise kişisel hijyen, iş yoğunluğu, insan yaşamı, koruyucu ekipman kullanımı, sosyal mesafe, temizlik ve bakım, çalışan sağlık güvencesi, ortak alanlar, havalandırma, ekipman kullanımı, çalışma saati, kapasite ve en az ağırlık değerine sahip olan ortam nemi kriterleri gelmektedir.

\section{Sonuçlar}

Günümüzde işletme ve çalışan performansını etkileyen en önemli unsur çalışma ortamlarıdır. Çalışan performansını çevresel ve psikolojik açıdan etkileyen faktörler çalışma ortamı düzeni ile doğru orantılıdır. Çalışma ortamlarında uzun çalışma saatleri insanları fiziksel ve psikolojik açıdan yormaktadır. Ergonominin amacı, çalışma ortamlarının insan faktörüne uygun şekilde düzenlenmesi ve insan iş uyumunun sağlanmasıdır. Ergonominin önemini benimsenmesi ve çalışma ortamlarının sağlıklı olması, çalışan verimini arttırır bu faaliyette işletme veriminin artmasına fayda sağlamaktadır. Bu yüzden işletmeyi etkileyen faktörler değerlendirilmeli ve önlemler alınmalıdır. 2020 yılında Covid-19 virüsünün dünyayı ele geçirmesi ile günlük hayat ve iş hayatımızdaki risklerle beraber alınması gereken önlemler de artmaktadır.

Bu çalışmada güncel bir konu olan Covid-19 virüsünün bulaşma riskinin yüksek olduğu kapalı çalışma ortamlarında insan sağlığını tehdit eden faktörler bulunmuş ve en öncelikli risk faktörü belirlenmiştir. Problemin amacının belirlenmesi ile amaca uygun yöntem ve kriterler belirlenmiştir. AHP yöntemi ile yapılan uygulamada üç ana kriter ve on dört alt kriter kullanılmıştır. Belirlenen kriterlerin uzman görüşler tarafından ikili karşıllaştırmaları yapılıış ve matrisler elde edilmiştir. Üç tane karar vericiden alınan cevapların tutarlılık oranları ve öncelik değerleri hesaplanmıştır.

Yapılan tüm çalışmalar sonucunda AHP yöntemi ile pandemi döneminde çalışma ortamlarını etkileyen öncelikli ana kriterin 'Psikolojik Risk Faktörü” olduğu sonucuna varılmıştır. Pandemi döneminde çalışan sağlığını etkileyen en az öneme sahip ana kriter ise "Yönetimsel Risk Faktörü" olduğu sonucuna varılmıştır. İş ve çalışma ortamları insanların fiziksel sağlıklarını etkiledikleri gibi ruhsal sağlığını da etkileyen önemli bir etken olmaktadır (Oruç,2020). Çalışma ortamlarının psikolojik açıdan uygun olmayan işletmelerde çalışanların yaşadığı stres, kaygı, üzüntü, iş kazaları ve iletişim eksikliği işletmelerin performansını da olumsuz yönde etkilemektedir. Oruç'un da çalışmasında görüldüğü üzere, haber yayıncılığında iş sağlığı ve güvenliği üzerine yaptığı çalışması ile psikolojik faktörlerin öneminden ve çalışanları etkileyen en önemli kriterin mobing olduğu belirlenmiştir (Oruç,2020).

AHP yöntemi ile problemin ana risk faktörlerinin kriter ağılıklarının bulunması ile alt kriterlerine ait kriter ağırlıklarıda bulunmuştur. Pandemi döneminde çalışma ortamlarında insanları etkileyen en önemli risk faktörünün "Çalışan Motivasyonu" olduğu sonucu ortaya çıkmıştır. Psikolojik Risk Faktörünün alt kriteri olan çalışan motivasyonu bu süreçte insanları ve işletmeyi etkileyen en önemli etmen olarak belirlenmiştir. Pandemi döneminde işletmeleri ve çalışanlar için en az riske sahip kriter ise "Ortam Nemi" faktörü olduğu sonucuna varılmıştır. Yılmaz'da, işgücü verimliliğini etkileyen faktörleri belirlediği çalışmasında çalışanın psiko-sosyal faktörler ve motivasyon açısından tatmin edilmezse, diğer faktörlerin etkisinin bir öneminin kalmayacağından bahsetmiştir (Yılmaz,2019).

Covid-19 pandemisi ile fiziksel ve sosyal kısıtlamalar beraberinde psikolojik sorunları da ortaya çıkarmaktadır. Pandemi döneminin uzun soluklu olarak devam etmesi insanlarda hastalığa karşı psikolojik sorunları oluşturmaktadır. İnsanların kendileri ve sevdiklerini koruma içgüdüsü ile hareket ettiği bu dönemde kaybetme korkusu, kısıtlamalardan dolayı ortaya çıkan yalnızlık, işyerleri ve sosyal paydaşlardan virüsün bulaşma korkusu ortaya çıkmaktadır (Tükel,2021). Pandemi ile ortaya çıkan psikolojik sorunlar insanın iş hayatını etkileyen faktörlerdendir. İşletmelerin temel hedefi olan ekonomideki yerlerini ve verimliliklerini arttırma gayesi bu süreçte çalışanlarını koruma ile sağlanmaktadır. Bu hedef doğrultusunda ergonomi ile stres faktörleri denetim altına alınıp, çalışma ortamından kaynaklanan olumsuz faktörler azaltılmalı ve çalışanın sağlığını iyileştirerek iş verimini yükselterek kazancın geri dönüşümü arttırılır (Düşüngülü vd.,2014). Çalışan performansının etkin ve verimli kullanılması için bireylerin ruhsal ve fiziksel gücünün iş için uygun ve 
sağlıklı olması gerekmektedir. Ergonomik çalışma ortamlarının fiziki şartlarının uygun ve çalışanların ruhsal sağlığını tatmin edici düzeyde olmalıdır. Performansın en büyük etkileyici faktörü olan çalışan motivasyonu, çalışmanın sonucunda da görüldüğü üzere pandemi döneminde çalışanlar için en önemli risk faktörü olduğu ortaya çıkmıştır. İnsanların değişen ortam ve sağlık koşullarına uyum sağlamakta zorlandığı ve bu uyumsuzluğu iş verimlerine de etki ettiği görülmektedir.

\section{Tartışma}

Pandemi dönemi devam etmektedir ve bu konuda yapılan çalışmalar kısıtlıdır. Bu çalışmanın diğer çalışmalara katkısı, pandemi döneminde çalışma ortamlarında insan sağlı̆̆ını etkileyen faktörlerin belirlenerek bu faktörlerin en aza indirilmesine yardımcı olmaktadır. Çalışma kapsamında kullanılan kriterler pandemi dönemine uygundur ve başka çalışmalar içinde kullanılabilir niteliktedir. Elde edilen sonuçlar işletmeler tarafından göz önünde bulundurulmalı ve risk faktörleri için önlemler alınmalıdır.

\section{Çıkar Çatışması}

Yazarlar tarafından herhangi bir çıkar çatışması beyan edilmemiştir.

\section{Ekler}

\section{A. SuperDecision AHP Modeli}

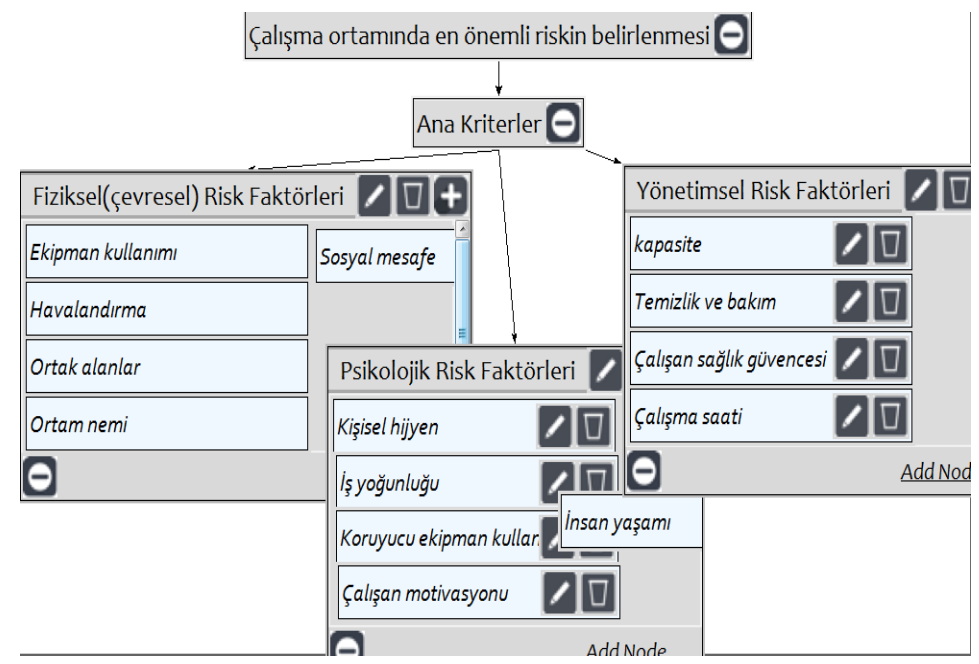

\section{B. SuperDecision Kriter Ağırlıkları}

\begin{tabular}{|c|c|}
\hline Ekipman kullanımı & 0.031140 \\
\hline Havalandırma & 0.037272 \\
\hline Ortak alanlar & 0.037622 \\
\hline Ortam nemi & 0.013156 \\
\hline Sosyal mesafe & 0.060500 \\
\hline İnsan yaşamı & 0.083320 \\
\hline İ̧̧yoğunluğu & 0.141294 \\
\hline Kişisel hijyen & 0.186570 \\
\hline $\begin{array}{l}\text { Koruyucu ekipman } \\
\text { kullanımı }\end{array}$ & 0.081440 \\
\hline Çalışan motivasyonu & 0.198878 \\
\hline kapasite & 0.020804 \\
\hline Temizlik ve bakım & 0.041836 \\
\hline Çalışan sağlık gūvencesi & 0.038210 \\
\hline Çalışma saati & 0.027958 \\
\hline
\end{tabular}




\section{Referanslar}

Açık Ders, Çok Ölçütlü Karar Verme Yöntemleri-III, Ankara Erişim adresi: https://acikders.ankara.edu.tr/course/view.php?id=5704 Erişim Tarihi: 05 Mart 2021

AKALP, G., \& ÖZOK, A. F. (2017). Ergonomik Risklerin Bulanik Mantik Yöntemi Ile Modellenmesi Ve Bir Uygulama. Mühendislik Bilimleri ve Tasartm Dergisi, 5, 69-79.

AKBAL, H., \& AKBAL, H. İ. (2020). Covid-19 Pandemi Sürecinde Uzaktan Eğitim İle İlgili Yaşanan Sorunların Öğrenci Bakış Açısına Göre AHP Yöntemi İle İncelenmesi. Bartın Üniversitesi İktisadi ve İdari Bilimler Fakültesi Dergisi, 11(22), 533-546.

Akpınar, T., Çakmakkaya, B. Y., \& Batur, N. (2018). Ofis çalışanlarının sağlığının korunmasında çözüm önerisi olarak ergonomi bilimi. Balkan ve Yakın Doğu Sosyal Bilimler Dergisi, 4(2), 76-98.

Ateş, Z. G. (2020). COVID-19’UN İŞVERENIN İş SAĞLIĞI VE GÜVENLIĞİ KONUSUNDA ALMASI GEREKEN ÖNLEMLERE ETKİSİ. İstanbul Ticaret Üniversitesi Sosyal Bilimler Dergisi, 19(38), 161-179.

BAKANLIĞI, Ç. V. S. G., \& MÜDÜRLÜĞÜ, İ. DÖKÜM ATÖLYELERINDEKİ İ̧ SAĞLIĞI VE GÜVENLIĞİ KOŞULLARININ ÇOK ÖLÇÜTLÜ KARAR VERME YÖNTEMLERIYLE DEĞERLENDIRILMESİ.

Baysal, G. (2018), Analitik Hiyerarşi Prosesi, Dokuz Eylül Üniversitesi, Ders Notları.

Camkurt, M. Z. (2007). İşyeri çalişma sistemi ve işyeri fiziksel faktörlerinin iş kazalari üzerindeki etkisi. TÜHíS İş Hukuku ve İktisat Dergisi, 2l(1), 80-106.

Çaloğlu Büyükselçuk, E., Üner, Ö., \& Özkan, C. (2005). KOBİ’lerde Çalışma Koşulları-Çalışan Memnuniyeti İlişkisi.

ÇETINKAYA, F., \& BAYKENT, G. (2017). İşyeri Çalışma Ortamı Koşullarının Ergonomik Yönden İncelenmesi (Örnek: Şekerleme Firmas1). Uşak Üniversitesi Fen ve Doğa Bilimleri Dergisi, 1(1), 15-31.

Dağdeviren, M., \& Tamer, E. R. E. N. (2001). Tedarikçi firma seçiminde analitik hiyerarşi prosesi ve 0-1 hedef programlama yöntemlerinin kullanılması. Gazi Üniversitesi Mühendislik Mimarlık Fakültesi Dergisi, 16(1), 41-52.

Devi, R. The Importance of a Healthy Working Environment in Business. Dünyada Covid-19 Pandemisi (2020).

DÜŞÜNGÜLÜ, F., TENGILIMOĞLU, D., \& ÖZTÜRK, Z. (2014). ÇALIŞMA ORTAMLARININ ERGONOMIK TASARIMININ AKADEMIK PERSONEL ÜZERINDEKI VERIMLILIĞİNE ETKİSI GAZI ÜNIVERSITESİ DIŞ HEKIMLIĞİ FAKÜLTESİ ÖRNEĞII. Ejovoc (Electronic Journal of Vocational Colleges), 4(4), 93-102.

EFE, Ö. F., \& Burak, E. F. E. Tekstil Sektöründe İș Kazalarına Sebep Olan Risk Faktörlerinin DEMATEL Yöntemiyle Analizi. Düzce Üniversitesi Bilim ve Teknoloji Dergisi, 7(3), 1162-1175.

Gülenç, İ. F., \& BİLGIN, G. A. (2010). YATIRIM KARARLARI İÇIN BİR MODEL ÖNERİSİ: AHP YÖNTEMİ-A MODEL PROPOSAL FOR INVESTMENT DECISIONS: AHP METHOD. Öneri Dergisi, 9(34), 97-107.

GÜVEN Nurçin, TALAŞLI İMALAT SEKTÖRÜNDE RİSK ANALİZİ, Yüksek lisans Tezi, 2019.

HAYTA, A. B. (2007). Çalışma ortamı koşullarının işletme verimliliği üzerine etkisi. Gazi Üniversitesi Ticaret ve Turizm Eğitim Fakültesi Dergisi, (1), 21-41.

Melek, I. Ş. I. K., \& DAĞSUYU, C. Bir Üretim İşletmesinde Departmanların Analitik Hiyerarşi Prosesi Yöntemi ile Ergonomik Analizi. Bitlis Eren Üniversitesi Fen Bilimleri Dergisi, 9(3), 1231-1241.

ÖLMEZ, H., ERGUN, İ., ENSARİ, M., \& Emine, C. A. N. (2021). Normalleşme Sürecinde Ofis Çalışmalarında Covid-19'u Önlemede Balık Kılçığı Yöntemi ile Sebep Sonuç Analizi. International Journal of Advances in Engineering and Pure Sciences, 33(1), 106-115.

Ömürbek, N., \& Aksoy, E. (2016). Bir petrol şirketinin çok kriterli karar verme teknikleri ile performans değerlendirmesi. Süleyman Demirel Üniversitesi İktisadi ve İdari Bilimler Fakültesi Dergisi, 21(3).

Önder, G., \& Önder, E. (2013). Yoğun Bakim Hemşirelerinin İş Tatminine Etki Eden Faktörlerin Önem Derecelerinin Analitik Hiyerarşi Prosesi Yöntemi İle Belirlenmesi (Determining the Precedence of Incentive Factors of Critical Care Unit Nurses' Job Satisfaction Using Analytic Hierarchy Process Technique). Ksü Iibf Dergisi, 3(2), 195-216.

ORUÇ, R. (2020). Haber Yayıncıllğında Çalışanların İş Sağllğı ve Güvenliği Bağlamında Bulanık Çok Ölçütlü Karar Verme Yöntemleriyle Değerlendirilmesi (Doctoral dissertation, Ankara Yıldırım Beyazıt Üniversitesi Fen Bilimleri Enstitüsü).

Önder, G., \& Önder, E. (2015). Analitik Hiyerarşi Süreci. Çok Kriterli Karar Verme Yöntemleri. Bursa: Dora. 
Pandemi Sonrası Çalışma Hayatı Beklentilerinin Araştırılması, HR Dergi, 23 Haziran (2020). Erişim adresi: https://hrdergi.com/pandemi-sonrasi-calisma-hayati-beklentileri-arastirmasi Erişim Tarihi: 05 Mart 2021

Pehlivanl1, U. (2019). Safety risk assessment for tunnel construction: application of AHP to Marmaray project (Master's thesis).

Pirinçci, S., \& Güngör, D. Ö. (2019). Çalışan Motivasyonunu Etkileyen Faktörlerin AHP Yöntemi İle Değerlendirilmesi: Bir İlaç Firması Uygulaması. İşletme Araştırmaları Dergisi, 11(4), 2512-2527.

Roser, M., Ritchie, H., Ortiz-Ospina, E., \& Hasell, J. (2020). Coronavirus pandemic (COVID-19). Our world in data.

Saaty, T. L. (2008). Decision making with the analytic hierarchy process. International journal of services sciences, 1(1), 83-98.

Samut, P. K. (2014). İki aşamalı çok kriterli karar verme ile performans değerlendirmesi: AHP ve TOPSIS yöntemlerinin entegrasyonu. Anadolu Üniversitesi Sosyal Bilimler Dergisi, 14(4), 57-67.

T.C Sağlık Bakanlığı Covid-19 Bilgilendirme Platformu (2020). Erişim adresi: https://covid19.saglik.gov.tr/TR-66113/covid-19.html Erişim tarihi: 05 Mart 2021

TC. Aile, Çalışma ve Sosyal Hizmetler Bakanlığı Covid-19 Döneminde Ortak Alanlar Kullanım Alanları Rehberi. Erişim adresi: https://www.csgb.gov.tr/media/68339/kiplas-covid-19-doneminde-ortak-kullanim-alanlari-rehberi-26022021.pdf Erişim Tarihi: 05 Mart 2021

Temel İstatistik Ders Notları, On Dokuz Mayız Üniversitesi, (2018). Erişim adresi: https://ist-fef.omu.edu.tr/tr/hakkimizda/ders-notlari Erişim Tarihi: 05 Mart 2021

Turgut, E. Ç. (2015). Tedarik Zinciri Yönetiminde AHP ve Bulanık AHP Yöntemi Kullanılarak Tedarikçilerin Performansının Ölçülmesi, Yeni Yöntem Önerileri Ve Uygulamaları. Yayımlanmamış Yüksek Lisans Tezi, Dokuz Eylül Üniversitesi Sosyal Bilimler Enstitüsü, İzmir.

Tükel, R. (2020). Covid-19 pandemi sürecinde ruh sağlı̆̆ı. Türk Tabipler Birliği Covid-19 Pandemisi Altıncı Ay Değerlendirme Raporu, 30, 2020.

ÜÇÜNCÜ, K. (2005). Ergonomi ve İş Etüdü.

Ülengin, F. (1992). Ulaşım Problemlerinde Analitik Hiyerarşi Yaklaşımı: İstanbul İçin Bir Uygulama. TMMOB İstanbul, 2, 103-121.

World Health Organization, Cleaning and disinfection of environmental surfaces in the context of COVID-19, (2020). Erişim adresi: https://www.who.int/publications/i/item/cleaning-and-disinfection-of-environmental-surfaces-inthe-context-of-covid-19 $\quad$ Erişim Tarihi: 05 Mart 2021

Vassilev, V., Genova, K., \& Vassileva, M. (2005). A brief survey of multicriteria decision making methods and software systems. Cybernetics and information technologies, 5(1), 3-13.

Yamaç, S. S. (2020). Performans değerlendirme sisteminin işletme verimliliği üzerine etkisi: Denizli Organize Sanayi Bölgesi’nde bir çalışma

YARALIOĞLU, K. (2001). Performans değerlendirmede analitik hiyerarşi proses. Dokuz Eylül Üniversitesi İktisadi İdari Bilimler Fakültesi Dergisi, 16(1).

YILMAZ, Y., \& ÖZDEMIR, D. S. İŞGÜCÜ VERIMLILİĞİNI ETKİLEYEN FAKTÖRLERİN ANALİŻ: BÜTÜNCÜL BİR YAKLAŞIM. 